\title{
Nondestructive Measurements in Support of Waste Isolation Pilot Plant at Rockwell Hanford Operations: Problems and Methods
}

May 1986

George A. Westsik

$$
\begin{aligned}
& \text { DO NOT WOROEILM } \\
& \text { COVER }
\end{aligned}
$$

Prepared for the U.S. Department of Energy under Contract DE-AC06-77RL01030

Rockwell International Rockwell Hanford Operations Richland, Washington 


\section{DISCLAIMER}

This report was prepared as an account of work sponsored by an agency of the United States Government. Neither the United States Government nor any agency thereof, nor any of their employees, makes any warranty, express or implied, or assumes any legal liability or responsibility for the accuracy, completeness, or usefulness of any information, apparatus, product, or process disclosed, or represents that its use would not infringe privately owned rights. Reference herein to any specific commercial product, process, or service by trade name, trademark, manufacturer, or otherwise, does not necessarily constitute or imply its endorsement, recommendation, or favoring by the United States Government or any agency thereof. The views and opinions of authors expressed herein do not necessarily state or reflect those of the United States Government or any agency thereof.

Printed in the United States of America

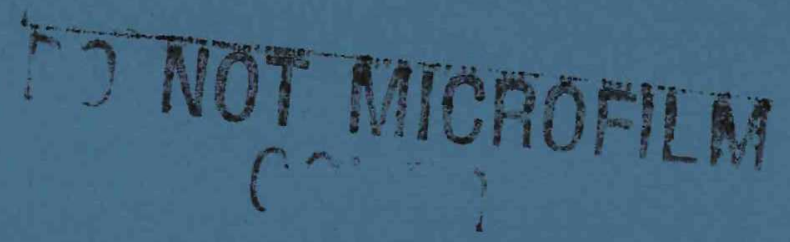




\section{DISCLAIMER}

This report was prepared as an account of work sponsored by an agency of the United States Government. Neither the United States Government nor any agency Thereof, nor any of their employees, makes any warranty, express or implied, or assumes any legal liability or responsibility for the accuracy, completeness, or usefulness of any information, apparatus, product, or process disclosed, or represents that its use would not infringe privately owned rights. Reference herein to any specific commercial product, process, or service by trade name, trademark, manufacturer, or otherwise does not necessarily constitute or imply its endorsement, recommendation, or favoring by the United States Government or any agency thereof. The views and opinions of authors expressed herein do not necessarily state or reflect those of the United States Government or any agency thereof. 


\section{DISCLAIMER}

Portions of this document may be illegible in electronic image products. Images are produced from the best available original document. 
This report was prepared as an account of work sponsored by an agency of the United States Government. Neither the United States Government nor any agency thereof, nor any of their employees, makes any warranty, express or implied, or assumes any legal liability or responsibility for the accuracy, completeness, or usefulness of any information, apparatus, product, or process disclosed, or represents that its use would not infringe privately owned rights. Reference herein to any specific commercial product, process, or service by trade name, trademark, manufacturer, or otherwise does not necessarily constitute or imply its endorsement, recommendation, or favoring by the United States Government or any agency thereof. The views and opinions of authors expressed herein do not necessarily state or reflect those of the United States Government or any agency thereof.

\section{Nondestructive Measurements in Support of Waste Isolation Pilot Plant at Rockwell Hanford Operations: Problems and Methods}

Date Manuscript Completed: May 1986

George A. Westsik

Safety and Quality Assurance

Prepared for the U.S. Department of Energy under Contract DE-AC06-77RL01030

Rıchland, Washıngton 99352 


\begin{abstract}
The 234-5Z Analytical Laboratory, located in the 200 West Area of the Hanford Site, has been requested to provide waste package measurement capability for both the Plutonium/Uranium Extraction (PUREX) Plant and Plutonium Finishing Plant (PFP) in support of the Waste Isolation Pilot Plant (WIPP) Waste Acceptance Criteria (WAC). The requested WIPP values are sensitive to changes in isotopic distribution. Unfortunately, the determination of the isotopic distribution of an individual waste item or drum is difficult. The problems and uncertainties encountered in providing the values are discussed. Also, examples of calculations for the WIPP-WAC are shown.
\end{abstract}




\section{CONTENTS}

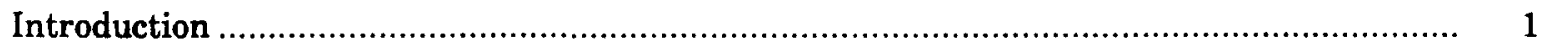

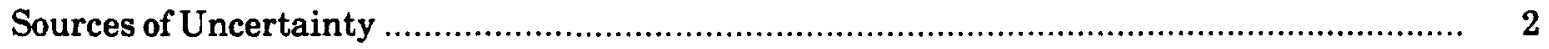

Magnitude of Uncertainties in Segmented Gamma Scan/Assay System Measurements and Isotopic-Sensitive Waste Isolation Pilot Plant Values ...................................... 7

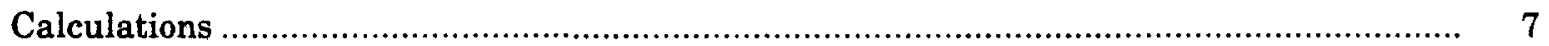




\section{INTRODUCTION}

The 234-5Z Analytical Laboratory, located in the 200 West area of the Hanford Site, has been requested to provide waste package measurement capability for both the Plutonium/Uranium Extraction (PUREX) Plant and Plutonium Finishing Plant (PFP) in support of Waste Isolation Pilot Plant (WIPP) Waste Acceptance Criteria (WAC). The requested WIPP values are sensitive to changes in isotopic distribution. Unfortunately, the determination of the isotopic distribution of an individual waste item or drum is difficult. The problems and uncertainties encountered in providing the values are discussed. Also, examples of calculations for the WIPP-WAC are shown.

Several scenarios encountered recently that can affect the WIPP values are listed below. The problems are more pronounced at PFP, but similar problems have the potential of becoming significant at PUREX.

The major obstacle to providing accurate values is the uncertainty in the isotopic distribution of the item being assayed. This uncertainty arises from several sources.

a. The segmented gamma scan assay system (SGSAS) measures $239 \mathrm{Pu}$ only and not the isotopes the WIPP values are most sensitive to.

b. Several material balance areas (MBAs) generate waste within a processing plant. Waste from one MBA will have a slightly different isotopic distribution than that from another MBA. Sometimes this occurs in the same MBA.

c. The ${ }^{241}$ Am content is established as of a certain date. However, there is the ingrowth of 241 Am over time. Waste generated a long time after the definition date will potentially have a much greater amount of ${ }^{241} \mathrm{Am}$. The difference in the WIPP value calculated, based on the definition date, versus the value calculated, based on the true $241 \mathrm{Am}$ content, could significantly affect the required calculations.

d. At the start of a new campaign the isotopic distributions of the material to be processed can change. The waste from the previous campaign may become mixed with waste from the new campaign. An extension of this is the possibility that waste from several years ago is mixed with waste from a recent campaign.

The sources of uncertainty are discussed in the following sections with examples of how the requested values are affected. Each will be treated separately but can occur simultaneously. The isotopic values used are from the Nondestructive Assay Isotopic System (NDAIS) measurements of feed and product items. There is no way to determine which of the scenarios will predominate. Due to characteristics of each processing area there will be a different place where a lump or pile of plutonium will hide until an exhaustive cleanout is performed. 


\section{SOURCES OF UNCERTAINTY}

\section{THE SEGMENTED GAMMA SCAN/ASSAY SYSTEM DOES NOT DETERMINE ISOTOPICS}

In areas where plutonium-bearing items are likely to have differing isotopic distributions, the fact that two items have the same relative $239 \mathrm{Pu}$ value (weight percent (wt\%)) does not ensure the masses of the other isotopes will be the same. This is important in areas like Miscellaneous Treatment (MT) at PFP and the area where feed is entered into $\mathrm{N}$ Cell at PUREX. The isotopic distribution of the feed stock prior to blending is not consistent.

As an example, take the case where $2 \%$ and $11 \% 240 \mathrm{Pu}$ material are blended to yield $6 \% 240 \mathrm{Pu}$ product as shown. The isotopic distribution used by the SGSAS to calculate the per gram WIPP values would be significantly different from the actual isotopic distributions. If the cans and plastic waste from the one isotopic group are disposed of at a different time from the waste of the second isotopic group, two or more waste drums would have large errors in the calculated WIPP values. One could not calculate the WIPP-required values based on an assumed stream average in this scenario.

\begin{tabular}{|c|c|c|c|}
\hline $\begin{array}{c}\text { Isotopic } \\
\text { distribution } \\
\text { (wt\%) }\end{array}$ & A & B & $\begin{array}{c}\text { Equal mass } \\
\text { mixture of } \\
\text { A\&B }\end{array}$ \\
\hline $238 \mathrm{Pu}$ & 0.005 & 0.082 & 0.044 \\
\hline $239 \mathrm{Pu}$ & 97.890 & 87.240 & 92.565 \\
\hline $240 \mathrm{Pu}$ & 2.065 & 11.440 & 6.752 \\
\hline $241 \mathrm{Pu}$ & 0.026 & 1.187 & 0.606 \\
\hline $242 \mathrm{Pu}$ & 0.013 & 0.051 & 0.032 \\
\hline $241 \mathrm{Am}$ & 0.506 & 1.439 & 0.972 \\
\hline
\end{tabular}

\begin{tabular}{|c|c|c|c|}
\hline $\begin{array}{c}\text { WIPP values } \\
\text { for waste drum }\end{array}$ & $\mathrm{A}$ & $\mathrm{B}$ & $\begin{array}{c}\text { Equal mass } \\
\text { mixture of } \\
\text { A\&B }\end{array}$ \\
\hline Ci/g & $1.11 \mathrm{E}-01$ & $1.37 \mathrm{E}+00$ & $7.40 \mathrm{E}-01$ \\
\hline alpha-Ci/g & $8.36 \mathrm{E}-02$ & $1.43 \mathrm{E}-01$ & $1.14 \mathrm{E}-01$ \\
\hline aPE-Ci/g & $7.26 \mathrm{E}-02$ & $1.38 \mathrm{E}-01$ & $1.05 \mathrm{E}-01$ \\
\hline bFGE/g & $9.80 \mathrm{E}-01$ & $9.02 \mathrm{E}-01$ & $9.41 \mathrm{E}-01$ \\
\hline watts & $2.60 \mathrm{E}-03$ & $4.60 \mathrm{E}-03$ & $3.60 \mathrm{E}-03$ \\
\hline
\end{tabular}

aPlutonium equivalent (transuranic activity). bFissile gram equivalent.

Although this is an extreme example, it is still credible and has probably happened. Another less extreme example is one where the items originate from the same site but have slightly different isotopes as shown. 


\begin{tabular}{|c|c|c|c|}
\hline Isotope (wt\%) & A & B & $\begin{array}{c}\text { Equal mass } \\
\text { mixture of } \\
\text { A\&B }\end{array}$ \\
\hline $238 \mathrm{Pu}$ & 0.012 & 0.013 & 0.012 \\
\hline $239 \mathrm{Pu}$ & 93.310 & 93.580 & 93.445 \\
\hline $240 \mathrm{Pu}$ & 6.397 & 6.089 & 6.243 \\
\hline $241 \mathrm{Pu}$ & 0.244 & 0.293 & 0.268 \\
\hline $242 \mathrm{Pu}$ & 0.036 & 0.026 & 0.031 \\
\hline $241 \mathrm{Am}$ & 0.327 & 0.017 & 0.172 \\
\hline
\end{tabular}

\begin{tabular}{|c|c|c|c|}
\hline $\begin{array}{c}\text { WIPP values } \\
\text { for waste drum }\end{array}$ & A & B & $\begin{array}{c}\text { Equal mass } \\
\text { mixture of } \\
\text { A\&B }\end{array}$ \\
\hline Ci/g & $3.38 \mathrm{E}-01$ & $3.77 \mathrm{E}-01$ & $3.57 \mathrm{E}-01$ \\
\hline alpha-Ci/g & $8.57 \mathrm{E}-02$ & $7.46 \mathrm{E}-02$ & $8.02 \mathrm{E}-02$ \\
\hline PE-Ci/g & $8.38 \mathrm{E}-02$ & $8.09 \mathrm{E}-02$ & $8.24 \mathrm{E}-02$ \\
\hline FGE/g & $9.40 \mathrm{E}-01$ & $9.44 \mathrm{E}-01$ & $9.42 \mathrm{E}-01$ \\
\hline watts & $2.70 \mathrm{E}-03$ & $2.30 \mathrm{E}-03$ & $2.50 \mathrm{E}-03$ \\
\hline
\end{tabular}

\section{MATERIAL BALANCE AREAS WITHIN A PROCESSING PLANT WITH DIFFERING MATERIAL ISOTOPES}

The isotopic distribution may be different for waste generated in the differing MBAs or even potentially in the same MBA. As an example, recently at PFP one MBA was processing freshly

\begin{tabular}{|c|c|c|}
\hline Isotope (wt\%) & A & B \\
\hline $238 \mathrm{Pu}$ & 0.032 & 0.082 \\
\hline $239 \mathrm{Pu}$ & 92.770 & 87.240 \\
\hline $240 \mathrm{Pu}$ & 6.366 & 11.440 \\
\hline $241 \mathrm{Pu}$ & 0.800 & 1.187 \\
\hline $242 \mathrm{Pu}$ & 0.031 & 0.051 \\
\hline $241 \mathrm{Am}$ & 0.006 & 1.439 \\
\hline
\end{tabular}




\begin{tabular}{|c|c|c|}
\hline $\begin{array}{c}\text { WIPP values } \\
\text { for waste drum }\end{array}$ & A & B \\
\hline Ci/g & $9.04 \mathrm{E}-01$ & $1.37 \mathrm{E}+00$ \\
\hline alpha-Ci/g & $7.76 \mathrm{E}-02$ & $1.43 \mathrm{E}-01$ \\
\hline PE-Ci/g & $9.59 \mathrm{E}-02$ & $1.38 \mathrm{E}-01$ \\
\hline FGE/g & $9.47 \mathrm{E}-01$ & $9.02 \mathrm{E}-01$ \\
\hline watts & $2.50 \mathrm{E}-03$ & $4.60 \mathrm{E}-03$ \\
\hline
\end{tabular}

separated $6 \% 240 \mathrm{Pu}$ material while another was processing aged $12 \% 240 \mathrm{Pu}$ material. Large errors in the WIPP values arise if complete isotopic information does not follow the waste drum to the SGSAS.

\section{CHANGE OF ISOTOPES AT CAMPAIGNS}

Related to the preceeding section is the situation where the isotopic composition of the material is changed at a change of campaigns. From extensive experience in NDA holdup measurements, it has been shown that even though the surfaces in a glove box have been cleaned, significant quantities of plutonium may remain. The isotopic mixtures shown in the following tables illustrate ideal operations and conservative assumptions about actual operations. The pure $(100 \%)$ isotopic composition represents an ideal clean-out from the previous campaign. The mixtures $(90 \%-10 \%)$ reflect actual operations where the isotopes from the previous campaign are decayed 6 mo from separation. The actual operations mixture is conservatively given as $90 \%-10 \%$. A recent case was closer to a 50\%-50\% mix.

\begin{tabular}{|c|c|r|r|c|}
\hline \multirow{2}{*}{ Isotope (wt\%) } & \multirow{2}{*}{$100 \% \mathrm{X}$} & \multicolumn{2}{|c|}{ Mixed of batch isotopics } & \multirow{2}{*}{$100 \% \mathrm{Y}$} \\
\cline { 3 - 4 } & & $90 \% \times 10 \% \mathrm{Y}$ & $10 \% \times 90 \% \mathrm{Y}$ & \\
\hline $238 \mathrm{Pu}$ & 0.0320 & 0.0370 & 0.0770 & 0.082 \\
\hline $239 \mathrm{Pu}$ & 92.7700 & 92.2200 & 87.7950 & 87.240 \\
\hline $240 \mathrm{Pu}$ & 6.3660 & 6.8730 & 10.9330 & 11.440 \\
\hline $241 \mathrm{Pu}$ & 0.8004 & 0.8363 & 1.1460 & 1.187 \\
\hline $242 \mathrm{Pu}$ & 0.0320 & 0.0339 & 0.0491 & 0.051 \\
\hline $241 \mathrm{Am}$ & 0.0000 & 0.0028 & 0.0019 & 0.000 \\
\hline
\end{tabular}




\begin{tabular}{|c|c|c|c|c|}
\hline \multirow{2}{*}{ WIPP values } & \multirow{2}{*}{$100 \% \mathrm{X}$} & \multicolumn{2}{|c|}{ Mixed of batch isotopics } & \multirow{2}{*}{$100 \% \mathrm{Y}$} \\
\cline { 3 - 4 } & & $90 \% \times 10 \% \mathrm{Y}$ & $10 \% \mathrm{X} 90 \% \mathrm{Y}$ & \\
\hline Ci/g & $9.04 \mathrm{E}-01$ & $9.43 \mathrm{E}-01$ & $1.28 \mathrm{E}+00$ & $1.32 \mathrm{E}+00$ \\
\hline alpha-Ci/g & $7.44 \mathrm{E}-02$ & $7.90 \mathrm{E}-02$ & $9.25 \mathrm{E}-02$ & $9.40 \mathrm{E}-02$ \\
\hline PE-Ci/g & $9.58 \mathrm{E}-02$ & $9.80 \mathrm{E}-02$ & $1.19 \mathrm{E}-01$ & $1.21 \mathrm{E}-01$ \\
\hline FGE/g & $9.47 \mathrm{E}-01$ & $9.43 \mathrm{E}-01$ & $9.06 \mathrm{E}-01$ & $9.02 \mathrm{E}-01$ \\
\hline watts & $2.40 \mathrm{E}-03$ & $2.50 \mathrm{E}-03$ & $3.00 \mathrm{E}-03$ & $3.00 \mathrm{E}-03$ \\
\hline
\end{tabular}

\section{INGROWTH OF ${ }^{241}$ Am}

There are many scenarios where the amount of $241 \mathrm{Am}$ would be uncertain. Due to the decay of $241 \mathrm{Pu}$ to ${ }^{241} \mathrm{Am}$, the quantity of ${ }^{241} \mathrm{Am}$ is constantly increasing. For a short campaign ( 3 to $6 \mathrm{mo}$ ) the amount of ingrowth will not be significant. However, it can become a problem in a larger campaign. The amount of potential impact depends on the initial $241 \mathrm{Pu}$ content, which is higher in $240 \mathrm{Pu}$ material.

Any time a quantity of plutonium is not discarded to waste or removed as stable product but remains in the processing area, the ingrowth becomes more significant. Recently, a unit at PFP completed a campaign to remove an old vacuum header. The material in it was several years old. The 241 Am content would make a significant impact on the WIPP values. Following are two sets of isotopes, each shown at four stages of decay: freshly separated, then six, twelve, and $60 \mathrm{mo}$.

\begin{tabular}{|c|c|c|c|c|}
\hline \multirow{2}{*}{ Isotope (wt\%) } & \multicolumn{4}{|c|}{ Months from plutonium-americium separation } \\
\cline { 2 - 5 } & 0 & 6 & 12 & 60 \\
\hline $238 \mathrm{Pu}$ & 0.0320 & 0.0320 & 0.0320 & 0.0310 \\
\hline $239 \mathrm{Pu}$ & 92.7700 & 92.7900 & 92.8100 & 92.9300 \\
\hline $240 \mathrm{Pu}$ & 6.3660 & 6.3670 & 6.3680 & 6.3740 \\
\hline $241 \mathrm{Pu}$ & 0.8004 & 0.7815 & 0.7629 & 0.6298 \\
\hline $242 \mathrm{Pu}$ & 0.0316 & 0.0320 & 0.0320 & 0.0320 \\
\hline $241 \mathrm{Am}$ & 0.0000 & 0.0190 & 0.0380 & 0.1710 \\
\hline
\end{tabular}




\begin{tabular}{|c|c|c|c|c|}
\hline \multirow{2}{*}{ WIPP values } & \multicolumn{4}{|c|}{ Months from plutonium-americium separation } \\
\cline { 2 - 5 } & 0 & 6 & 12 & 60 \\
\hline Ci/g & 9.04 E-01 & $8.85 \mathrm{E}-01$ & $8.67 \mathrm{E}-01$ & $7.34 \mathrm{E}-01$ \\
\hline alpha-Ci/g & $7.76 \mathrm{E}-02$ & $7.81 \mathrm{E}-02$ & $7.87 \mathrm{E}-02$ & $8.32 \mathrm{E}-02$ \\
\hline PE-Ci/g & $9.59 \mathrm{E}-02$ & $9.55 \mathrm{E}-02$ & $9.53 \mathrm{E}-02$ & $9.37 \mathrm{E}-02$ \\
\hline FGE/g & $9.47 \mathrm{E}-01$ & $9.47 \mathrm{E}-01$ & $9.47 \mathrm{E}-01$ & $9.45 \mathrm{E}-01$ \\
\hline watts & $2.50 \mathrm{E}-03$ & $2.50 \mathrm{E}-03$ & $2.50 \mathrm{E}-03$ & $2.60 \mathrm{E}-03$ \\
\hline
\end{tabular}

\begin{tabular}{|c|c|c|c|c|}
\hline \multirow{2}{*}{ Isotope (wt\%) } & \multicolumn{4}{|c|}{ Months from plutonium-americium separation } \\
\cline { 2 - 5 } & 0 & 6 & 12 & 60 \\
\hline $238 \mathrm{Pu}$ & 0.082 & 0.082 & 0.081 & 0.079 \\
\hline $239 \mathrm{Pu}$ & 87.240 & 87.270 & 87.290 & 87.460 \\
\hline $240 \mathrm{Pu}$ & 11.440 & 11.440 & 11.450 & 11.470 \\
\hline $241 \mathrm{Pu}$ & 1.187 & 1.159 & 1.132 & 0.935 \\
\hline $242 \mathrm{Pu}$ & 0.051 & 0.051 & 0.051 & 0.051 \\
\hline $241 \mathrm{Am}$ & 0.000 & 0.028 & 0.056 & 0.254 \\
\hline
\end{tabular}

\begin{tabular}{|c|c|c|c|c|}
\hline \multirow{2}{*}{ WIPP values } & \multicolumn{4}{|c|}{ Months from plutonium-americium separation } \\
\cline { 2 - 5 } & 0 & 6 & 12 & 60 \\
\hline Ci/g & $1.32 \mathrm{E}+00$ & $1.29 \mathrm{E}+00$ & $1.26 \mathrm{E}+00$ & $1.07 \mathrm{E}+00$ \\
\hline alpha-Ci/g & $9.40 \mathrm{E}-02$ & $9.50 \mathrm{E}-02$ & $9.59 \mathrm{E}-02$ & $1.03 \mathrm{E}-01$ \\
\hline PE-Ci/g & $1.21 \mathrm{E}-01$ & $1.21 \mathrm{E}-01$ & $1.21 \mathrm{E}-01$ & $1.18 \mathrm{E}-01$ \\
\hline FGE/g & $9.02 \mathrm{E}-01$ & $9.01 \mathrm{E}-01$ & $9.01 \mathrm{E}-01$ & $8.98 \mathrm{E}-01$ \\
\hline watts & $3.00 \mathrm{E}-03$ & $3.00 \mathrm{E}-03$ & $3.10 \mathrm{E}-03$ & $3.30 \mathrm{E}-03$ \\
\hline
\end{tabular}




\section{MAGNITUDE OF UNCERTAINTIES IN SEGMENTED GAMMA SCAN/ASSAY SYSTEM MEASUREMENTS AND ISOTOPIC-SENSITIVE WASTE ISOLATION PILOT PLANT VALUES}

It should be noted that the magnitude of uncertainty in the assay value generated by the SGSAS can be large in comparison to the uncertainties listed previously. Due to the nature of the SGSAS assay, at lower gram levels the uncertainty is a higher percentage of the assay value than at higher gram levels. Background levels also have a large impact on the uncertainty calculations. High background areas such as in room 19 of 236-Z give rise to higher uncertainties at the same gram levels that are found in an item.

At low gram levels (less than 50 to $100 \mathrm{~g}$ plutonium) the SGSAS assay uncertainties will predominate. Uncertainties due to isotopic composition will predominate at higher gram levels. Which factor will predominate in any one situation, however, must be evaluated for that specific situation.

\section{Calculations}

\section{CALCULATION OF WASTE ISOLATION PILOT PLANT PER GRAM VALUES}

The values and factors used in the previous calculations are noted in the following tables. These are included to ensure consistency among users. Due to slight variations in the half-lives in published literature, compared to those accepted by national standards organizations, the curie per gram of isotope value calculated for some isotopes may change.

\section{HALF-LIVES OF RADIONUCLIDES AND ALPHA BRANCHING RATIOS}

\begin{tabular}{|c|c|c|}
\hline Isotope & Half-life (yr)a & $\begin{array}{c}\text { Alpha branching } \\
\text { ratiosb }\end{array}$ \\
\hline $238 \mathrm{Pu}$ & 87.79 & 1.0000000 \\
\hline $239 \mathrm{Pu}$ & 24082.00 & 1.0000000 \\
\hline $240 \mathrm{Pu}$ & 6537.00 & 1.0000000 \\
\hline $241 \mathrm{Pu}$ & 14.35 & 0.0000245 \\
\hline $242 \mathrm{Pu}$ & $376300.00 \mathrm{~b}$ & 1.0000000 \\
\hline $241 \mathrm{Am}$ & 434.10 & 1.0000000 \\
\hline
\end{tabular}

aSource (except for 242Pu): "Calibration Techniques for the

Calorimetric Assay of Plutonium-Bearing Solids Applied to Nuclear

Materials Control", ANSI N15.22-1975, p. 21, approved June 5, 1975.

bSource: Table of Isotopes, Seventh Edition, ed. C. Michael

Lederer and Virginia S. Shirley, pp. 1457, 1464, 1469, 1472, 1474, 1477, John Wiley \& Sons, Inc., New York, New York (1878). 
RHO-QA-SA-26 P

CALCULATED CURIE AND ALPHA CURIE PER GRAM FACTORS

\begin{tabular}{|c|c|c|}
\hline Isotope & $\begin{array}{c}\text { Curies per gram of } \\
\text { isotope }\end{array}$ & $\begin{array}{c}\text { Alpha-curies per } \\
\text { gram of isotope }\end{array}$ \\
\hline $238 \mathrm{Pu}$ & 17.119320 & 17.119320 \\
\hline $239 \mathrm{Pu}$ & 0.061964 & 0.061964 \\
\hline $240 \mathrm{Pu}$ & 0.226640 & 0.226640 \\
\hline $241 \mathrm{Pu}$ & 103.298100 & 0.003924 \\
\hline $242 \mathrm{Pu}$ & 0.003924 & 0.002531 \\
\hline $241 \mathrm{Am}$ & 3.432510 & 3.432510 \\
\hline
\end{tabular}

The equations used in the above calculations are as follows.

Curies per gram of isotope $(\mathrm{Ci} / \mathrm{gi})=\Lambda \mathrm{N} / 3.7 \mathrm{E}+10$

where $\lambda$ is the decay constant of the isotope

$$
\Lambda=\frac{\ln 2}{\text { half-life }^{*} 3.1558 \mathrm{E}+07}
$$

and $\mathrm{N}$ is the number of atoms in one gram of the isotope

$$
\mathrm{N}=\frac{6.02 \mathrm{E}+23}{\text { element weight of isotope }}
$$

The factor $3.7 \mathrm{E}+10$ is the definition of a curie and equals the number of disintegrations per second of an isotope per curie.

As noted earlier the WIPP factors are calculated for a specific isotopic distribution. The isotopic distribution for a recently measured item is the basis for the calculations below.

The curies per gram of plutonium is calculated by:

$\mathrm{Ci} / \mathrm{g} \mathrm{Pu}=$ isotope mass fraction * curies per gram of isotope 


\begin{tabular}{|c|c|c|c|}
\hline Isotope & $\begin{array}{c}\text { Mass fraction } \\
\text { of isotope per } \\
\text { gram of } \\
\text { plutonium }\end{array}$ & $\begin{array}{c}\text { Curies per } \\
\text { gram of } \\
\text { isotope }\end{array}$ & $\begin{array}{c}\text { Curies per } \\
\text { gram of } \\
\text { plutonium }\end{array}$ \\
\hline $238 \mathrm{Pu}$ & 0.000322 & 17.119320 & 0.005512 \\
\hline $239 \mathrm{Pu}$ & 0.927700 & 0.061964 & 0.057484 \\
\hline $240 \mathrm{Pu}$ & 0.063660 & 0.226640 & 0.014427 \\
\hline $241 \mathrm{Pu}$ & 0.008004 & 103.298100 & 0.826798 \\
\hline $242 \mathrm{Pu}$ & 0.000314 & 0.003924 & 0.000001 \\
\hline $241 \mathrm{Am}$ & 0.000060 & 3.432510 & 0.000189 \\
\hline TOTAL & & & 0.904411 \\
\hline
\end{tabular}

The number of alpha-curies per gram of isotope is calculated by

alpha-Ci/g of isotope $=\mathrm{Ci} / \mathrm{g}$ of isotope $*$ isotope alpha branching ratio

or

alpha-ci/g of $\mathrm{Pu}=$ isotope mass fraction * alpha-Ci/g of isotope

\begin{tabular}{|c|l|c|c|}
\hline Isotope & $\begin{array}{c}\text { Curies per } \\
\text { gram of } \\
\text { plutonium }\end{array}$ & $\begin{array}{c}\text { Alpha } \\
\text { branching } \\
\text { ratio }\end{array}$ & $\begin{array}{c}\text { Alpha-Ci/g } \\
\text { plutonium }\end{array}$ \\
\hline $238 \mathrm{Pu}$ & 0.0055124 & 1.0000000 & 0.005512 \\
\hline $239 \mathrm{Pu}$ & $\mathbf{0 . 0 5 7 4 8 4}$ & 1.0000000 & 0.057484 \\
\hline $240 \mathrm{Pu}$ & 0.014427 & 1.0000000 & 0.014427 \\
\hline $241 \mathrm{Pu}$ & 0.826798 & 0.0000245 & 0.000020 \\
\hline $242 \mathrm{Pu}$ & 0.000001232 & 1.0000000 & 0.000001 \\
\hline $241 \mathrm{Am}$ & 0.000188788 & 1.0000000 & 0.000189 \\
\hline TOTAL & & & 0.077633 \\
\hline
\end{tabular}


The 239Pu Equivalent Transuranic Activity (PE-Ci) per gram of plutonium factor is calculated as follows:

$\mathrm{PE}-\mathrm{Ci} / \mathrm{g} \mathrm{Pu}=$ isotope $\mathrm{Ci} / \mathrm{g} \mathrm{Pu}$ * isotope $\mathrm{PE}-\mathrm{Ci}$ factor

\begin{tabular}{|c|c|c|c|}
\hline Isotope & Ci/g plutonium & $\begin{array}{c}\text { PE-Ci } \\
\text { correction } \\
\text { factor* }\end{array}$ & $\begin{array}{c}\text { PE-Ci/g } \\
\text { plutonium }\end{array}$ \\
\hline $238 \mathrm{Pu}$ & 0.005512 & 1 & 0.005512 \\
\hline $239 \mathrm{Pu}$ & 0.057484 & 1 & 0.057484 \\
\hline $240 \mathrm{Pu}$ & 0.014427 & 1 & 0.014427 \\
\hline $241 \mathrm{Pu}$ & 0.826798 & $1 / 45$ & 0.018373 \\
\hline $242 \mathrm{Pu}$ & 0.000001 & 1 & 0.000001 \\
\hline $241 \mathrm{Am}$ & 0.000189 & $1 / 3$ & 0.000063 \\
\hline TOTAL & & & 0.095860 \\
\hline
\end{tabular}

*Source: RHO-MA-222 Rev. 3, "Hanford Radioactive Solid Waste Packaging, Storage, and Disposal Requirements, Appendix C.

The 239Pu FGE per gram of plutonium factor is calculated as follows:

FGE/g Pu = Isotope Mass Fraction * Isotope FGE factor

\begin{tabular}{|c|c|c|c|}
\hline Isotope & Ci/g plutonium & $\begin{array}{c}\text { FGE } \\
\text { correction } \\
\text { factor* }\end{array}$ & $\begin{array}{c}\text { PE-Ci/g } \\
\text { plutonium }\end{array}$ \\
\hline $238 \mathrm{Pu}$ & 0.000322 & $9 / 80$ & 0.000036 \\
\hline $239 \mathrm{Pu}$ & 0.927700 & 1 & 0.927700 \\
\hline $240 \mathrm{Pu}$ & 0.063660 & $9 / 400$ & 0.001432 \\
\hline $241 \mathrm{Pu}$ & 0.008004 & $9 / 4$ & 0.018009 \\
\hline $242 \mathrm{Pu}$ & 0.000314 & $9 / 1200$ & 0.000002 \\
\hline $241 \mathrm{Am}$ & 0.000006 & $9 / 480$ & 0.000001 \\
\hline TOTAL & & & 0.947181 \\
\hline
\end{tabular}

"Source: RHO-MA-222 Rev. 3, "Hanford Radioactive Solid Waste Packaging, Storage, and Disposal Requirements, Appendix B. 
The thermal power of an item is expressed in watts and is calculated using a watts per gram of plutonium (W/g) factor. The calculation of the watt per gram factor is shown below.

Watts/g Pu $=$ Isotope Mass Fraction * isotope specific wattage

\begin{tabular}{|c|c|c|c|}
\hline Isotope & $\begin{array}{c}\text { Isotope mass } \\
\text { fraction }\end{array}$ & $\begin{array}{c}\text { Watts per gram } \\
\text { of isotope* }\end{array}$ & W/g plutonium \\
\hline $238 \mathrm{Pu}$ & 0.000322 & 0.5675700 & 0.000183 \\
\hline $239 \mathrm{Pu}$ & 0.927700 & 0.0019288 & 0.001789 \\
\hline $240 \mathrm{Pu}$ & 0.063660 & 0.0070824 & 0.000451 \\
\hline $241 \mathrm{Pu}$ & 0.008004 & 0.0034120 & 0.000027 \\
\hline $242 \mathrm{Pu}$ & 0.000314 & 0.0001159 & 0.000000 \\
\hline $241 \mathrm{Am}$ & 0.000060 & 0.1142000 & 0.000007 \\
\hline TOTAL & & & 0.002457 \\
\hline
\end{tabular}

"Source: "Calibration Techniques for the Calorimetric Assay of Plutonium-Bearing Solids Applied to Nuclear Materials Control," ANSI N15.22-1975, p. 21, approved June 5, 1975. 


\section{DISTRIBUTION}

\section{Number of Copies}

Offsite

2

U.S. Department of Energy

Technical Information Center

Oak Ridge, Tennessee 37830

$\underline{\text { Onsite }}$

2

U.S. Department of Energy

Richland Operations Office

Richland, Washington 99352

G. T. Orton

K. L. Thomas

32

Rockwell Hanford Operations

M. D. Aichele

R. B. Bendixsen

K. A. Buchanan

D. L. Duncan

D. M. Fazzari

J. T. Foster

D. R. Groth

R. A. Hamilton

R. P. Heintz

T. A. Lane

R. M. Lipinski

C. S. Louie

J. B. Maier

E. J. Manthos

S. H. Norton

H. E. Oens

L. R. Ogletree

H. R. Perkins

E. F. Serbia

H. E. Smith

W. H. Steel

C. S. Sutter

G. A. Westsik (5)

Publication Services, Group 3, 231-Z

Document Control (4) 